\title{
Traditional and Non-traditional Forms of Political Participation in
}

\author{
Multigenerational Households*
}

\author{
Mark Hill ${ }^{\dagger}$
}

April 2019

\begin{abstract}
The relationship between demographic trends and political participation is seldom overlooked, as even minute movements within the population can result in the systematic alteration of behavior among the American electorate. Throughout the past two decades, the United States has experienced consistent growth in the number of multigenerational households, seemingly correlated with cultural and economic changes across the country. According to one Census report, more than 4.3 million households, or roughly $5.6 \%$ of all households in the United States, are multigenerational. Surprisingly, the political behavior of such a significant demographic subgroup has yet to be analyzed in any meaningful way. It is unknown if and how such households differ from traditional households with regard to political participation and engagement. Using data from the Integrated Public Use Microdata Series Current Population Survey (IPUMS-CPS) Voter Supplement for years 2000-2016 and Civic Engagement Supplement for the years of 2008-2011 and 2013, I am able to identify the individuals living in multigenerational households and assess their propensity to engage in a variety of political acts. Across a multitude of regression models and specifications of participation, I show that those living in multigenerational households participate at a significantly lower rate than those living in traditional households controlling for key demographics variables that have previously been shown to influence participation. Additionally, the panel structure of the IPUMS-CPS microdata creates the unique opportunity for a conditional differences-in-differences analysis with matching, so those who were not living in a multigenerational household at time $t$ but were in time $t+1$ can be compared to similar individuals who don't live in such a household in either time period. Those living in multigenerational households vote at a lower rate in presidential, midterm, and local elections, and are also less likely to engage in other forms of political engagement such as talking to family about politics, contacting an elected official, and being a part of organizations.
\end{abstract}

\section{Introduction}

The literature surrounding political behavior and participation in the United States is often able to provide a vast amount of insight as to how certain population subgroups participate in politically related activities,

\footnotetext{
* This paper was presented at the New England Political Science Association annual conference for the Campaigns, Political Participation, and Electoral Institutions discussion panel, 4/26/2019.

$\dagger$ Department of Government, Harvard University, markhill@g.harvard.edu
} 
while also explaining exactly why each subgroup participates at the observed rates (Brady, Verba and Schlozman, 1995; Dahan and Monogan, 2016; Gerber, Green and Larimer, 2008; Hopkins and Williamson, 2012; Rosenstone and Hansen, 1993). In order to do this, such literature must achieve two goals. First, identify the subgroups of people, usually based on groupings of similar demographic characteristics, that behave significantly different from one another, and second, uncover what actually causes these groups do behave as they do. Such knowledge is relevant not only for political scientists who desire to understand and explain how the political system works, but for politicians who are running for office or creating targeted policy to influence the behavior of specific people. (Green, 2015; Holbrook and McClurg, 2005).

Being able to accurately determine which groups of people are more or less likely to participate in politics alters the behavior of elected officials, which, in turn, impacts the behavior of the American electorate (Hersh, 2015). This paper attempts to achieve the first of these two goals, to introduce the reader to a population subgroup, namely, adults living in multigenerational households, that has been largely overlooked within the field of political science, and to provide evidence that living in a multigenerational household significantly impacts one's political participation relative to those not living in a multigenerational household.

According to a 2012 Census report on the topic of multigenerational households, a multigenerational household (MGHH, from here on) is defined as a household that consists of three or more generations of the same family (Lofquist, 2012). An example could be the head of a household, at least one parent, and at least one child. There are other, less strict definitions that have been proposed that would include more households, such as one that skips a generation, meaning it would have two different generations separated by more than one generation. An example of this could be grandparents and a grandchild, but no parent in between, also known as grandfamilies. Another definition includes both types of households mentioned previously and households that have two adult generations, a parent and at least one child usually twentytwo years or older (Multigenerational Households, 2019). Moving forward, this manuscript will adhere to the definition of a MGHH offered by the 2012 Census report, a household with three or more generations of the same family. ${ }^{1}$

\footnotetext{
${ }^{1}$ It should be noted that other definitions do exist, and how a researcher chooses to define MGHHs will change the MGHH proportion in a given sample.
} 


\subsection{The Multigenerational Household}

It is possible that the reader is unfamiliar with MGHHs, however, it is not the case that this population has gone unnoticed. Pew Research Center has published a brief report on their website that examines trends among MGHHs in the United States using data from the American Community Survey (Cohn and Passel, 2016). ${ }^{2}$ The main takeaways are that the proportion of MGHHs in the United States has been consistently increasing since about 1980, and at an increased rate since about the mid-2000s, since about 1990, young adults are most likely to live in a MGHH, and while all racial/ethnic groups have seen growth in the proportion that live in MGHHs, those who are White are much less likely to live in a MGHH compared to other races.

Niederhaus and Graham (2013) dub multigenerational living "one of the hottest trends in housing," while recent research by Muennig, Jiao and Singer (2018) suggests that those living in MGHHs may have more financial resources and are less lonely, resulting in increased social capital and improved longevity. It is clear that the trend of increasing MGHHs in the Untied States has garnered a sufficient amount of attention. There exist multiple reports and analyses through multiple different media, yet the impacts on political behavior and engagement of this trend have yet to be assessed.

What has been published seems to present MGHHs in a generally positive manner, so one may initially suspect that those living in MGHHs are more inclined to be politically engaged, or at least not differ from those living in traditional single-family homes. Especially considering the claim that living in such a household reduces stress and financial constraints, while increasing social capital (Muennig, Jiao and Singer, 2018). The resource model of political participation proposed by Brady, Verba and Schlozman (1995) would suggest that reduced cognitive burden and pooling of family resources leads to an increase in participation, while increased social capital should result in more civic engagement, which leads to increased trust and political participation (Putnam, 2000). However, multiple analyses conducted in this manuscript suggest that those who live in a MGHH are less civically and politically engaged than those who live in traditional households, which begs the question, why is this the case? This question leaves a clear path for the trajectory

\footnotetext{
${ }^{2}$ In their methodology, Pew notes that the Census Bureau has a narrower definition of what constitutes a MGHH than the definition used by Pew in this report. As a result, Pew identifies more MGHHs than the Census Bureau, and therefore, this manuscript.
} 
of political science research concerning MGHHs, and while I offer some suggestions for why this may be the case, my main goal is to provide sufficient evidence that the trend of increasing MGHHs has a place in the sphere of political participation research as living in such a household significantly impacts political behavior.

\section{Data}

I choose to assess the political behavior of individuals that live in MGHHs using the Integrated Public Use Microdata Series Current Population Survey (IPUMS-CPS) data compiled from CPS basic monthly surveys, which are administered monthly to over 65,000 households across the United States and obtain thorough demographic data for each individual living in a sampled household. (Flood et al., 2018). Specifically, I use the November basic monthly CPS data from presidential and midterm election years starting in 2000 through 2016. ${ }^{3,4}$ The November basic monthly during these election years contains a Voting and Registration Supplement, which records whether or not one voted in the most recent November election and why they did not vote among those eligible to vote.

I also include November 2009, 2011, and 2013 in my data as the basic monthly from these years has the additional advantage of a Civic Engagement Supplement, which seeks to measure "one's level of or involvement in empowerment and political action, groups and networks, trust and solidarity, information and communication, and social cohesion and inclusion" (Flood et al., 2018), along with frequency of voting in local elections for the years 2011 and 2013. Therefore, I am, in a sense, working with three subsets of the data described above. The civic engagement subset which is years 2008-11 and 2013, the national elections subset, which is 2000-16 biannually, and the local elections subset which is years 2011 and 2013.

\subsection{Defining a Multigenerational Household}

To identify which individuals in the data are living in MGHHs I leverage the "RELATE" variable present in the IPUMS-CPS data. This variable explains how each individual in the household relates to the head of the household. The relevant categories are Head, Parent, Child, Grandchild. This means that in following with

\footnotetext{
${ }^{3}$ Biannually from 2000 to 2016 .

${ }^{4}$ Any time a year is mentioned in this manuscript one should understand I am referring to the November basic monthly and it's supplemental topics from that year.
} 
the three generation definition of MGHHs, the possible ways a household could be identified as multigenerational is if there exists at least a head, parent, and child, or a head, child, and grandchild, or a head, parent, and grandchild. ${ }^{5}$ Unfortunately, the "RELATE" variable lacks further granularity, and simply classifies other members of the family as "Other relative," which means this classification method will undoubtedly miss a few MGHHs present in the data. For example, head, child-in-law, grandchild would be missed, as would head, grandparent, child. I propose that these are fairly uncommon relationships within a household and would not make up a significant portion of MGHHs in the data even if they could be identified. Figure 1 displays the proportion of adults for each year in the data that have been determined to live in a MGHH. Figure 1: Proportion of Adults Living in Multigenerational Households; November CPS Samples 2000-2016

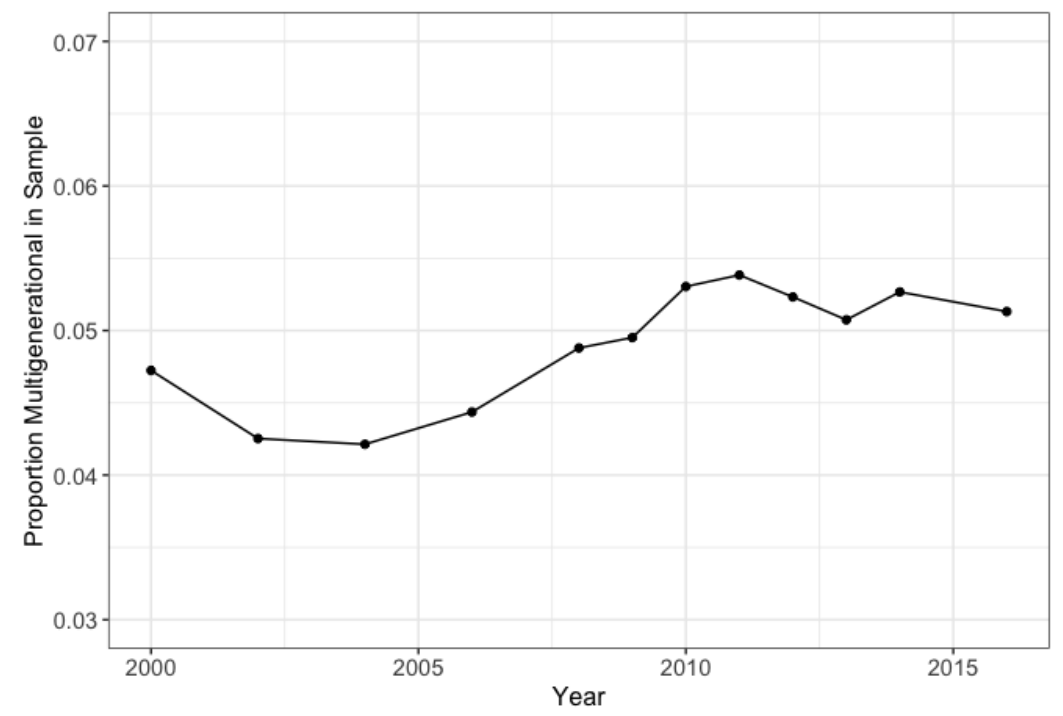

Note: Non-citizens and others who may be ineligible to vote are included in this figure.

It is promising that the trend of individuals living in a MGHH present in this data follows the trends noted in other data. More specifically, a slow but steady increase in the early 2000s followed by a more rapid increase during the recession, and then a leveling off, but not a decrease (Carrns, 2017; Cohn and Passel, 2016; Muennig, Jiao and Singer, 2018). Now that it is clear how MGHHs will be identified in the data, I will explain the different measures of political and civic engagement that will be used in the subsequent analyses.

\footnotetext{
${ }^{5}$ Before defining households as multigenerational or not, households with more than one family living in them were removed from the data. This was approximately $6 \%$ of the original data.
} 


\subsection{Measures of Political and Civic Engagement}

The most common, and as a result, one of the most researched forms of political participation is voting (Aldrich, 1993; Campbell, 1964; Fowler and Dawes, 2008; Gerber, Green and Larimer, 2008), which is why a significant portion of this manuscript will analyze the impact of living in a MGHH on voter turnout. For the national election subset of the data described above, each U.S. citizen over the age of 18 has a binary variable indicating whether or not they voted in that year's November election, and for the local election subset an individual reports how often they vote in local elections on an ordinal scale where the options are Never, Rarely, Sometimes, and Always. Figure 2 plots state and county-level voter turnout for midterm and presidential elections and the proportion of individuals that live in a MGHH for each year in the national elections subset.

Figure 2: Turnout vs Multigenerational Household Population for Presidential and Midterm Elections; 20002016
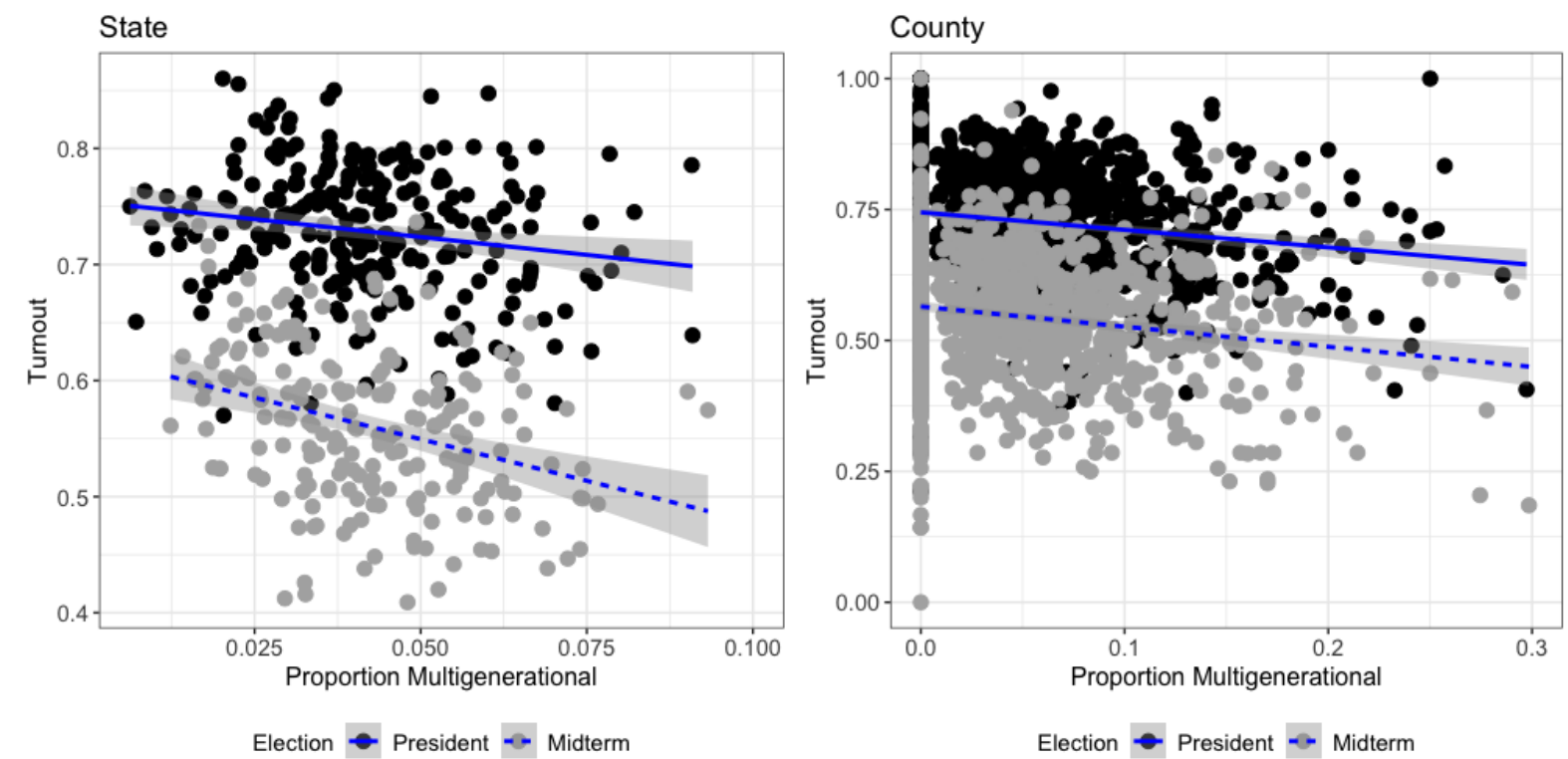

Note: The IPUMS-CPS identifies less than $45 \%$ of counties due to privacy concerns. Extreme outliers on the $x$-axis are removed from the plot, if anything these made the slopes of these lines steeper. The data is subset to those who are citizens of the United States and at least 18 years old.

Unsurprisingly, turnout for midterm elections is significantly lower than turnout for presidential elections. This figure also provides the first hint that living in a MGHH may impact political participation. For both states and counties across midterm and presidential elections, as the proportion of individuals living in a MGHH increases, the proportion of voting individuals decreases. 
Along with voter turnout, the civic engagement supplemental questions in the civic engagement subset of the data (2008-11, and 2013) allow me to create a composite civic engagement score for each individual by summing across the nine measures related to civic engagement that are available in all five years of the data. ${ }^{6}$ Most of these measures are binary, i.e. an individual simply answers yes or no to whether they engaged in such an activity within the past twelve months. The two questions that ask "how often" are recoded to range from 0 to 1 so they carry the same weight as the other yes/no measures. Therefore, the composite civic engagement measure for each person can range from 0 , if they never took part in any of the nine activities, to 9 if they took part in every activity mentioned and frequently talked to neighbors and talked to their family about politics. The data with the composite scores is then subset to remove every individual that did not answer at least one of the nine questions so as to not artificially inflate the scores with zeros. The calculated engagement scores range from 0 to 9 , have a mean of 1.93 and a median of 1.5 . The distribution of these scores presented in Figure 5 in the Appendix shows that they are highly right-skewed.

Figure 3 plots the average civic engagement score against the proportion of MGHHs for each state-year and county-year pair across the years 2008-11 and 2013. One can see that the same trend as above emerges; states and counties with a higher proportion of individuals that live in MGHHs are less civically engaged.

\footnotetext{
${ }^{6}$ The civic engagement measures that are present across all five years of the data are "[buying] or boycott[ing] a specific product or service in the past 12 months due to the social or political values of the company," "serv[ing] on a committee or as an officer of any group or organization," "participat[ing] in a service or civic organization," "participat[ing] in a school group, neighborhood group, or community association," "participating in a religious organization," "how often a respondent talks with any neighbors," " how often a respondent discusses politics with family or friends during a typical month," and "whether a respondent has contacted or visited a public official to express his or her opinion" (Flood et al., 2018).
} 
Figure 3: Civic Engagement vs Multigenerational Household Population; 2008-2011 \& 2013
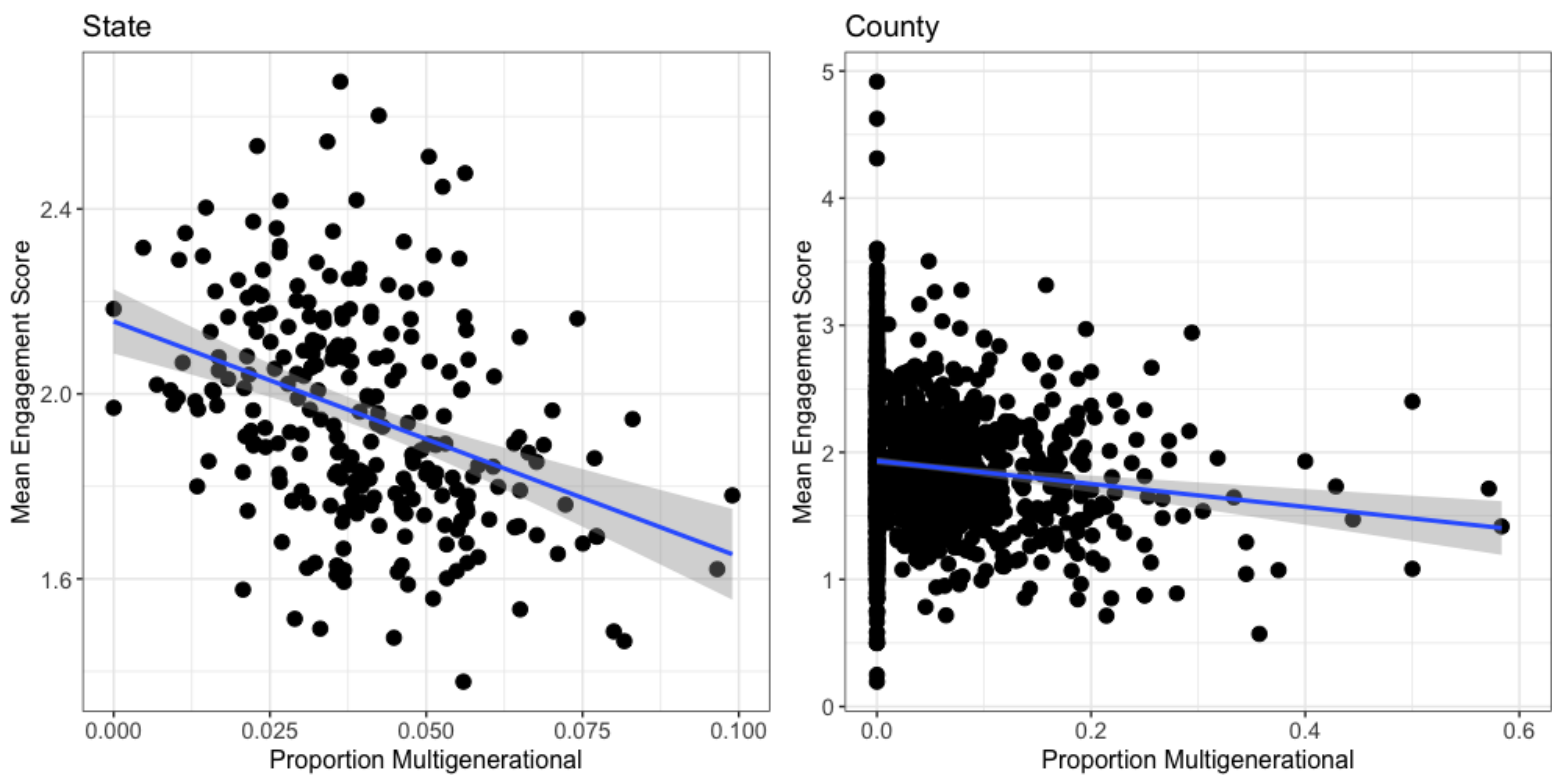

Note: The IPUMS-CPS identifies less than $45 \%$ of counties due to privacy concerns. Extreme outliers on the x-axis are removed from the plot, if anything these made the slopes of these lines steeper. The data is subset to those who are citizens of the United States and at least 18 years old. The mean engagement score is the average of the sum of binary indicators of whether or not an individual chooses to boycott a product based on political values, whether they serve on a committee, whether they are part of a civic organization, whether they take part in a community association, religious organization, and recreational organization, how frequently they talk to their neighbors, and how frequently they discuss politics with family members. The frequency variables are rescaled to range from 0 to 1 . As such, a 1 unit decrease in the y-axis can be interpreted as going from doing one of these activities to not doing one of these activities. Those who did not provide an answer to any of the civic engagement questions are removed from the data.

However, Figures 2 and 3 do not present anything more than simple correlations and are far from conclusive evidence, as we know that living in a MGHH is highly correlated with racial background and immigration status (Cohn and Passel, 2016), and likely increased financial burden, as this population increased during the recession, all of which are strongly correlated with political participation (Brady, Verba and Schlozman, 1995; Tam Cho, 1999). It may be useful to visually display exactly how MGHHs differ from traditional single-family households along a multitude of demographic and political variables and how this has changed over time prior to moving into the analyses. Figure 4 plots the means for both individuals that live in Non-MGHHs and and those that live in MGHHs across many variables that have been standardized to have a mean of 0 and a standard deviation of 1 for years 2000, 2008, and 2016. 
Figure 4: Standardized Means of Demographic and Political Variables Across Household Types; 2000, 2008, 2016

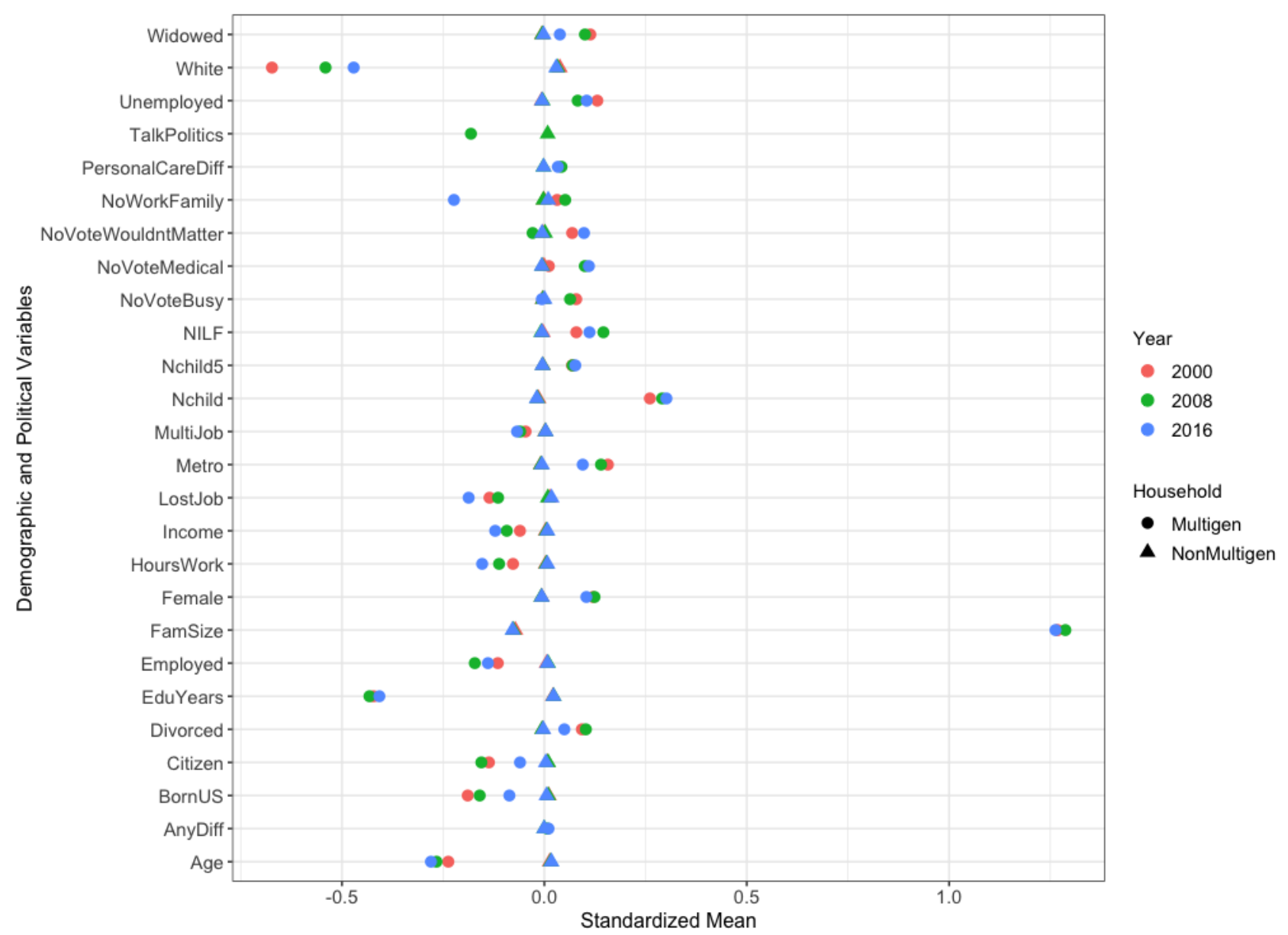

Note: Such little variation is observed among the non-multigenerational households because there are often over 100,000 observations for each demographic variable, and over $90 \%$ of these are non-multigenerational.

The most notable takeaways from Figure 4 are MGHHs are significantly less white, although that gap is decreasing, they are much less likely to talk about politics with family even though there are more family members in the household, only in recent years are those living in MGHHs more likely to be absent from work due to family obligations, they have more children and a much larger family in the house, work fewer hours, are less educated, are less likely to be a citizen or born in the U.S., although this gap is also decreasing, and are younger. While it is useful to observe the differences between the two populations, this also serves a benchmark to determine if the demographics of individuals living in MGHHs in my data are consistent with what has been observed by others in the past. Based on the findings from Cohn and Passel (2016), this is largely consistent. The analyses laid out in the next section will attempt to isolate the effect of living in a 
MGHH accounting for many other confounding demographic variables.

\section{Methods}

The analyses in this manuscript can be broken into two parts. First, I use regressions on repeated crosssections to test the effects of living in a MGHH on voter turnout while also attempting to control for common factors influencing turnout in local and national elections, which may also be correlated with

living in a MGHH. Second, I leverage the panel structure and linking capability of the IPUMS-CPS basic monthly survey data to perform a differences-in-differences analysis with coarsened exact matching that lends itself to a more straightforward causal interpretation (Iacus, King and Porro, 2012). Throughout this manuscript, any continuous variables present in the models have been standardized by centering them at mean 0 and dividing by $2 \sigma$, which has the benefit of improving model convergence and matrix inversion, issues that sometimes arise when variables have drastically different scales. This adjustment also makes it easier to compare coefficients across different variables. Using this scaling method, any continuous variable coefficients can now be interpreted roughly the same as binary variable coefficients, the effect of going from the low to the high end of the scale (Gelman, 2008).

\subsection{Repeated Cross-section Regression Models}

The first model I apply to the national election data is a linear probability model. This model is advantageous in that each coefficient can be directly interpreted as the marginal effect on the probability that someone votes, all else constant. Additionally, one need not worry about the incidental parameter problem when including fixed effects that plagues non-linear models if the number of time periods, $T$, is not sufficiently large (Lancaster, 2000). Variables included in this model are demographics that have been shown to influence political participation such as age, years of education, gender, race, income, whether or not one was born in the U.S., employment status, martial status and metro area. I also include variables that differentiate MGHHs from traditional households such as family size, number of children, whether a person has a physical or cognitive difficulty, and if they have been a resident in their current household for less than a year. Finally, I include state and year fixed effects as midterm election years have decreased turnout, and many voting and 
registration laws that influence turnout are enacted at the state-level.

While the effects estimated by a linear probability model may be easier to interpret, whether or not one votes is, by the nature of voting, a binary outcome. Therefore, the next set of regression models included in this analysis are logistic models. These models include the same explanatory variables, however when including state and year effects, I opt to do so using a random effects logistic model rather than a fixed effects logistic model in an attempt to overcome the incidental parameter problem. This also allows me to include one additional model where the effect of living in a MGHH varies by state and year.

The final model utilizes the local election data rather than the national election data used by the linear and logistic models. It is an ordered logistic model that examines the effect of living in a MGHH on voting in local elections. I use an ordered model here because the outcome, frequency of voting in local elections, is an ordered list with possible options Never, Rarely, Sometimes, and Always. This model controls for the same variables above ${ }^{7}$, and includes state fixed-effects in the final specification.

\subsection{Differences-in-differences Design}

The above regression models give one a sense of how living in a MGHH influences one's propensity to vote, yet it is difficult to apply a causal interpretation to repeated cross-sections. Fortunately, the sampling design of the CPS basic monthly survey allows about $50 \%$ of sampled individuals to be linked to their responses from the previous year. This means that for respondents who completed the November 2008 survey with the civic engagement supplement, about half can be linked to their responses on the same supplement in November 2009. Using unique individual IDs, I subset the civic engagement data to individuals that can be linked to their responses from the previous year. These are people who initially took the survey in 2008 and could be linked to 2009, another group of people who initially took the survey in 2009 and could be linked to 2010, and a third group of people who initially took the survey in 2010 and could be linked to 2011. All the individuals who live in a MGHH during the first wave are removed from the data. This means each individual in the final data set has two waves of data, and everyone in the first wave does not live in a MGHH.

Given this setup, it can be observed whose living situation changes by the time they take the second

\footnotetext{
${ }^{7}$ Except if someone has lived in their home for less than a year as this is collinear.
} 
wave of the survey, and how one's civic engagement score changes from $t$ to $t+1$. This bodes well for a differences-in-differences design because with panel data in two time periods the sample average treatment effect among the treated (SATT) can be estimated as:

$$
\tau_{S A T T}=E\left[Y_{i 1}-Y_{i 0} \mid G_{i}=1\right]-E\left[Y_{i 1}-Y_{i 0} \mid G_{i}=0\right]
$$

where, in the context of this data, $Y_{i 1}$ is an individuals civic engagement score in the second wave, $Y_{i 0}$ is an individuals civic engagement score in the first wave, $G_{i}=1$ are the people that change to living in a MGHH, and $G_{i}=0$ are the people who remain in a traditional household. This is easily identified by regressing the change in civic engagement for each person on a binary indicator of whether or not their household changed to a MGHH. For this to be the case, treatment, i.e. whether one enters a MGHH, must be independent of idiosyncratic shocks that influence civic engagement. This is unlikely, especially in this circumstance, but such independence may hold conditional on covariates. Since this is the case, I opt for a conditional differences-in-differences approach using regression. This means the SATT can be estimated as:

$$
Y_{i 1}-Y_{i 0}=\delta+X_{i}^{\prime} \beta+\tau G_{i}+\left(\epsilon_{i 1}-\epsilon_{i 0}\right)
$$

where $\tau$ is the SATT, $X$ is a matrix of pretreatment covariates, and $\delta$ is the pretreatment mean in the control group.

When using this approach there are a few things to consider. First, is the parallel trends assumption. This states that the potential trend under control must be the same for the control and treated groups conditional on covariates. See Figure 6 in the Appendix for the trend of pretreatment civic engagement score for both groups across the three years it is available. ${ }^{8}$

Second, the conclusions drawn by regression differences-in-differences can be influenced by model dependence, and one way to reduce model dependence is by matching treated units to comparable control units. I decide to implement a coarsened exact matching strategy using pretreatment, or wave 1 , covariates to address this concern. Because the number of observations is so large to begin with, I decide to first match

\footnotetext{
${ }^{8}$ This is not a traditional parallel trends plot so the reader should be sure to read the figure's footnote.
} 
on state, year, age, family size, number of children, born in the United States, income, years of education, race, gender, and metro area. I then take this matching even further by matching on the previously mentioned covariates, and add martial status, employment status, hours usually worked, and whether or not the individual has a physical or cognitive difficulty. Continuous variables are coarsened into bins. ${ }^{9}$

As a final robustness check, I repeat the above matching analysis, but subset the civic engagement data to include people whose marital status and employment status remains unchanged across waves. The reason for this is that one may suggest an individual moves into a MGHH after losing their job, or becoming widowed or divorced, and this has been shown to negatively affect political participation and engagement (Hobbs, Christakis and Fowler, 2014; Stoker and Jennings, 1995). The next section presents results of the methods described above.

\section{Results}

Table 1 below presents the results of the linear probability model. ${ }^{10}$ Before controlling for important demographic characteristics, it is estimated in column 1 that living in a MGHH reduces the probability of voting by 13 percentage points. Column 2 presents the results after controlling for demographics that one would expect to influence political participation and including state and year fixed-effects. The effect of living in a MGHH shrinks to a decrease of 4 percentage points, yet is still significant. Column 3 adds the physical or cognitive difficulty variable and whether the individual has lived in their house for less than one year variable, and column 4 adds year and state fixed-effects on top of that. Both columns 3 and 4 estimate living in a MGHH significantly decreases the probability of voting by about 3 percentage points.

Table 2 presents the results of logistic regression. ${ }^{11}$ Column 1 shows an effect of living in a MGHH of -.548 on the log-odds scale. Using the divide by 4 rule to get the upper bound of this effect in terms of marginal probability (Gelman and Hill, 2007), one can see the maximal effect of living in a MGHH is $-.548 / 4=-13.7$ percentage points which is comparable to the linear probability model. Columns 4 and 5

\footnotetext{
${ }^{9}$ The bins for age are 18-26, 27-36, 37-56, 57-66, 67-85. The bins for family size are $1,2,3-4,5,6-13$. The bins for number of children are $0,1,2,3,4-6,7-9$. The bins for income range from $\$ 0$ to $\$ 150,000$ in increments of $\$ 10,000$. The bins for years of education are 0-8, 9-12, 13-16, and 17-20. The bins for hours usually worked are 0-5, 6-20, 21-45, 46-55, 56-80, 81-120, and 121-160.

${ }^{10}$ This table is compressed to save space. See Table 7 in the Appendix for an expanded version.

${ }^{11}$ Expanded version available in Appendix, Table 8
} 
include all demographic variables as well as state and year random-effects, additionally, column 5 allows the effect of living in a MGHH to vary by year and state rather than remaining constant as it does with fixed effects. The estimated effect of living in a MGHH on the log-odds scale is -0.131 and -0.171 respectively, which translate to a maximal effect of -3.3 and -4.3 percentage points, again very similar to the estimate effects on the linear model. Overall, these models suggest living in a MGHH significantly reduces the probability an individual will vote during a midterm or presidential election by roughly 3 percentage points.

Table 1: Effect of Living in a Multigenerational Household on Turnout in Presidential or Midterm Elections for CPS Voter Supplement Respondents; 2000-2016

\begin{tabular}{|c|c|c|c|c|}
\hline & \multicolumn{4}{|c|}{ Voted in Presidential or Midterm Election } \\
\hline & $(1)$ & $(2)$ & $(3)$ & $(4)$ \\
\hline Multigenerational & $\begin{array}{c}-0.132^{* * *} \\
(0.003)\end{array}$ & $\begin{array}{c}-0.040^{* * *} \\
(0.003)\end{array}$ & $\begin{array}{c}-0.028^{* * *} \\
(0.004)\end{array}$ & $\begin{array}{c}-0.026^{* * *} \\
(0.004)\end{array}$ \\
\hline Age & & $\begin{array}{c}0.264^{* * *} \\
(0.002)\end{array}$ & $\begin{array}{c}0.229^{* * *} \\
(0.002)\end{array}$ & $\begin{array}{c}0.232^{* * *} \\
(0.002)\end{array}$ \\
\hline $\mathrm{Age}^{2}$ & & $\begin{array}{c}-0.051^{* * *} \\
(0.003)\end{array}$ & $\begin{array}{c}-0.016^{* * *} \\
(0.003)\end{array}$ & $\begin{array}{c}-0.018^{* * *} \\
(0.003)\end{array}$ \\
\hline Years Education & & $\begin{array}{c}0.206^{* * *} \\
(0.001)\end{array}$ & $\begin{array}{c}0.194^{* * *} \\
(0.002)\end{array}$ & $\begin{array}{c}0.194^{* * *} \\
(0.002)\end{array}$ \\
\hline Female & & $\begin{array}{c}0.036^{* * *} \\
(0.001)\end{array}$ & $\begin{array}{c}0.035^{* * *} \\
(0.001)\end{array}$ & $\begin{array}{c}0.035^{* * *} \\
(0.001)\end{array}$ \\
\hline Income & & $\begin{array}{c}0.096^{* * *} \\
(0.001)\end{array}$ & $\begin{array}{c}0.083^{* * *} \\
(0.002)\end{array}$ & $\begin{array}{c}0.080^{* * *} \\
(0.002)\end{array}$ \\
\hline Born in U.S. & & $\begin{array}{c}0.072^{* * *} \\
(0.002)\end{array}$ & $\begin{array}{c}0.070^{* * *} \\
(0.003)\end{array}$ & $\begin{array}{c}0.072^{* * *} \\
(0.003)\end{array}$ \\
\hline Metro Area & & $\begin{array}{c}-0.003^{*} \\
(0.001)\end{array}$ & $\begin{array}{c}0.001 \\
(0.002)\end{array}$ & $\begin{array}{l}0.004^{*} \\
(0.002)\end{array}$ \\
\hline Family Size & & $\begin{array}{l}0.006^{* *} \\
(0.002)\end{array}$ & $\begin{array}{c}-0.022^{* * *} \\
(0.003)\end{array}$ & $\begin{array}{c}-0.018^{* * *} \\
(0.003)\end{array}$ \\
\hline Children & & $\begin{array}{c}-0.015^{* * *} \\
(0.002)\end{array}$ & $\begin{array}{l}-0.003 \\
(0.002)\end{array}$ & $\begin{array}{c}-0.005^{*} \\
(0.002)\end{array}$ \\
\hline Any Phys./Cog. Difficulty & & & $\begin{array}{c}-0.080^{* * *} \\
(0.002)\end{array}$ & $\begin{array}{c}-0.081^{* * *} \\
(0.002)\end{array}$ \\
\hline Resident $<1 \mathrm{yr}$ & & & $\begin{array}{c}-0.130^{* * *} \\
(0.002)\end{array}$ & $\begin{array}{c}-0.131^{* * *} \\
(0.002)\end{array}$ \\
\hline Constant & $\begin{array}{c}0.655^{* * *} \\
(0.001)\end{array}$ & $\begin{array}{c}0.527^{* * *} \\
(0.008)\end{array}$ & $\begin{array}{c}0.502^{* * *} \\
(0.008)\end{array}$ & $\begin{array}{c}0.578^{* * *} \\
(0.010)\end{array}$ \\
\hline State FE & & $\checkmark$ & & $\checkmark$ \\
\hline Year FE & & $\checkmark$ & & $\checkmark$ \\
\hline Race & & $\checkmark$ & $\checkmark$ & $\checkmark$ \\
\hline Employment Status & & $\checkmark$ & $\checkmark$ & $\checkmark$ \\
\hline Marital Status & & $\checkmark$ & $\checkmark$ & $\checkmark$ \\
\hline $\mathrm{N}$ & 698,620 & 604,812 & 363,028 & 363,028 \\
\hline $\mathrm{R}^{2}$ & 0.003 & 0.200 & 0.167 & 0.212 \\
\hline Adjusted $\mathrm{R}^{2}$ & 0.003 & 0.199 & 0.167 & 0.212 \\
\hline
\end{tabular}

${ }^{*} \mathrm{p}<.05 ;{ }^{* *} \mathrm{p}<.01 ;{ }^{* * *} \mathrm{p}<.001$

Note: Standard errors in parentheses. Coefficients are from a linear probability model. Continuous variables are standardized by centering them at 0 and dividing by $2 \sigma$. As such, these coefficients can be interpreted as the effect of moving from the low end to the high end, roughly the same as how a binary variable would be interpreted. Observations are dropped in columns 3 and 4 because the physical or cognitive difficult variable was introduced to the CPS in 2008. 
Table 2: Effect of Living in a Multigenerational Household on Turnout in Presidential or Midterm Elections for CPS Voter Supplement Respondents, Logistic; 2000-2016

\begin{tabular}{|c|c|c|c|c|c|}
\hline & \multirow{3}{*}{$\begin{array}{c}\text { logistic } \\
(1)\end{array}$} & \multirow{3}{*}{\multicolumn{2}{|c|}{ 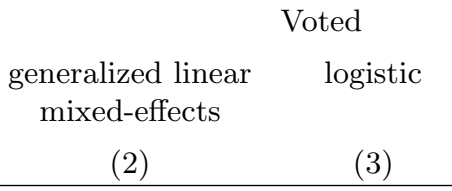 }} & \multirow{2}{*}{\multicolumn{2}{|c|}{$\begin{array}{l}\text { generalized linear } \\
\text { mixed-effects }\end{array}$}} \\
\hline & & & & & \\
\hline & & & & (4) & $(5)$ \\
\hline Multigenerational & $\begin{array}{c}-0.548^{* * *} \\
(0.012)\end{array}$ & $\begin{array}{c}-0.192^{* * *} \\
(0.016)\end{array}$ & $\begin{array}{c}-0.132^{* * *} \\
(0.020)\end{array}$ & $\begin{array}{c}-0.131^{* * *} \\
(0.020)\end{array}$ & $\begin{array}{c}-0.171^{* * *} \\
(0.042)\end{array}$ \\
\hline Age & & $\begin{array}{c}1.413^{* * *} \\
(0.009)\end{array}$ & $\begin{array}{c}1.203^{* * *} \\
(0.012)\end{array}$ & $\begin{array}{c}1.296^{* * *} \\
(0.012)\end{array}$ & $\begin{array}{c}1.296^{* * *} \\
(0.012)\end{array}$ \\
\hline $\mathrm{Age}^{2}$ & & $\begin{array}{c}-0.111^{* * *} \\
(0.014)\end{array}$ & $\begin{array}{l}0.058^{* *} \\
(0.018)\end{array}$ & $\begin{array}{c}0.047^{*} \\
(0.019)\end{array}$ & $\begin{array}{l}0.046^{*} \\
(0.019)\end{array}$ \\
\hline Years Education & & $\begin{array}{c}1.218^{* * *} \\
(0.008)\end{array}$ & $\begin{array}{c}1.129^{* * *} \\
(0.010)\end{array}$ & $\begin{array}{c}1.194^{* * *} \\
(0.010)\end{array}$ & $\begin{array}{c}1.195^{* * *} \\
(0.010)\end{array}$ \\
\hline Female & & $\begin{array}{c}0.173^{* * *} \\
(0.006)\end{array}$ & $\begin{array}{c}0.166^{* * *} \\
(0.008)\end{array}$ & $\begin{array}{c}0.175^{* * *} \\
(0.008)\end{array}$ & $\begin{array}{c}0.175^{* * *} \\
(0.008)\end{array}$ \\
\hline Income & & $\begin{array}{c}0.570^{* * *} \\
(0.008)\end{array}$ & $\begin{array}{c}0.465^{* * *} \\
(0.009)\end{array}$ & $\begin{array}{c}0.474^{* * *} \\
(0.010)\end{array}$ & $\begin{array}{c}0.475^{* * *} \\
(0.010)\end{array}$ \\
\hline Born in U.S. & & $\begin{array}{c}0.363^{* * *} \\
(0.013) \\
(0.016)\end{array}$ & $\begin{array}{c}0.347^{* * *} \\
(0.016) \\
(0.019)\end{array}$ & $\begin{array}{c}0.378^{* * *} \\
(0.017) \\
(0.020)\end{array}$ & $\begin{array}{c}0.378^{* * *} \\
(0.017) \\
(0.020)\end{array}$ \\
\hline Metro Area & & $\begin{array}{c}-0.028^{* * *} \\
(0.008)\end{array}$ & $\begin{array}{l}-0.005 \\
(0.009)\end{array}$ & $\begin{array}{c}0.013 \\
(0.011)\end{array}$ & $\begin{array}{c}0.013 \\
(0.011)\end{array}$ \\
\hline Family Size & & $\begin{array}{c}0.046^{* * *} \\
(0.011)\end{array}$ & $\begin{array}{c}-0.084^{* * *} \\
(0.014)\end{array}$ & $\begin{array}{c}-0.065^{* * *} \\
(0.014)\end{array}$ & $\begin{array}{c}-0.064^{* * *} \\
(0.014)\end{array}$ \\
\hline Children & & $\begin{array}{c}-0.088^{* * *} \\
(0.010)\end{array}$ & $\begin{array}{c}-0.037^{* *} \\
(0.013)\end{array}$ & $\begin{array}{c}-0.052^{* * *} \\
(0.013)\end{array}$ & $\begin{array}{c}-0.053^{* * *} \\
(0.013)\end{array}$ \\
\hline Any Phys./Cog. Difficulty & & & $\begin{array}{c}-0.414^{* * *} \\
(0.012)\end{array}$ & $\begin{array}{c}-0.447^{* * *} \\
(0.013)\end{array}$ & $\begin{array}{c}-0.447^{* * *} \\
(0.013)\end{array}$ \\
\hline Resident $<1 \mathrm{yr}$ & & & $\begin{array}{c}-0.606^{* * *} \\
(0.012)\end{array}$ & $\begin{array}{c}-0.650^{* * *} \\
(0.012)\end{array}$ & $\begin{array}{c}-0.650^{* * *} \\
(0.012)\end{array}$ \\
\hline Constant & $\begin{array}{c}0.640^{* * *} \\
(0.003)\end{array}$ & $\begin{array}{l}-0.142 \\
(0.160)\end{array}$ & $\begin{array}{c}0.011 \\
(0.043) \\
\end{array}$ & $\begin{array}{l}-0.064 \\
(0.241)\end{array}$ & $\begin{array}{l}-0.061 \\
(0.229)\end{array}$ \\
\hline$\overline{\text { State RE }}$ & & $\checkmark$ & & $\checkmark$ & $\checkmark$ \\
\hline Year RE & & $\checkmark$ & & $\checkmark$ & $\checkmark$ \\
\hline State Varying Slopes & & & & & $\checkmark$ \\
\hline Year Varying Slopes & & & & & $\checkmark$ \\
\hline Race & & $\checkmark$ & $\checkmark$ & $\checkmark$ & $\checkmark$ \\
\hline Employment Status & & $\checkmark$ & $\checkmark$ & $\checkmark$ & $\checkmark$ \\
\hline Marital Status & & $\checkmark$ & $\checkmark$ & $\checkmark$ & $\checkmark$ \\
\hline $\mathrm{N}$ & 698,620 & 604,812 & 363,028 & 363,028 & 363,028 \\
\hline
\end{tabular}

Moving to local elections, Table 3 displays the results for how demographic characteristics influence the frequency of voting in local elections. ${ }^{12}$ Because this table shows the results of an ordered logit model, Column 2 suggests that when controlling for demographics that are expected to significantly influence voting, living in a MGHH reduces the probability of moving up one category on the ordinal scale, i.e. from rarely

\footnotetext{
${ }^{12}$ Expanded version in Appendix Table 9.
} 
to sometimes, by $9.2 / 4=2.3$ percentage points. Including state fixed-effects and a binary indicator for year as in column 3 slightly changes this estimate to a decrease of 2.5 percentage points.

Table 3: Effect of Living in a Multigenerational Household on Turnout in Local Elections for CPS Civic Engagement Supplement Respondents, Ordered Logistic; 2011 \& 2013

\begin{tabular}{|c|c|c|c|}
\hline & $\begin{array}{l}\text { Vote in Loc } \\
\text { (1) }\end{array}$ & $\begin{array}{l}\text { l Elections: } \\
(2)\end{array}$ & 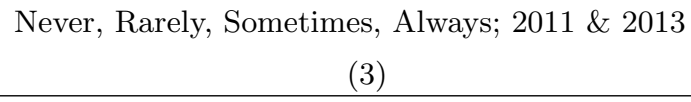 \\
\hline Multigenerational & $\begin{array}{c}-0.522^{* * *} \\
(0.028)\end{array}$ & $\begin{array}{c}-0.092^{* *} \\
(0.033)\end{array}$ & $\begin{array}{c}-0.099^{* *} \\
(0.033)\end{array}$ \\
\hline Age & & $\begin{array}{c}1.442^{* * *} \\
(0.018)\end{array}$ & $\begin{array}{c}1.457^{* * *} \\
(0.018)\end{array}$ \\
\hline $\mathrm{Age}^{2}$ & & $\begin{array}{c}-0.254^{* * *} \\
(0.029)\end{array}$ & $\begin{array}{c}-0.250^{* * *} \\
(0.029)\end{array}$ \\
\hline Years Education & & $\begin{array}{c}0.877^{* * *} \\
(0.014)\end{array}$ & $\begin{array}{c}0.881^{* * *} \\
(0.014)\end{array}$ \\
\hline Female & & $\begin{array}{c}0.074^{* * *} \\
(0.012)\end{array}$ & $\begin{array}{c}0.077^{* * *} \\
(0.012)\end{array}$ \\
\hline Income & & $\begin{array}{c}0.282^{* * *} \\
(0.015)\end{array}$ & $\begin{array}{c}0.279^{* * *} \\
(0.015)\end{array}$ \\
\hline Born in U.S. & & $\begin{array}{c}0.531^{* * *} \\
(0.025)\end{array}$ & $\begin{array}{c}0.534^{* * *} \\
(0.026)\end{array}$ \\
\hline Metro Area & & $\begin{array}{c}-0.189^{* * * *} \\
(0.015)\end{array}$ & $\begin{array}{c}-0.167^{* * *} \\
(0.016)\end{array}$ \\
\hline Family Size & & $\begin{array}{c}-0.083^{* * *} \\
(0.023)\end{array}$ & $\begin{array}{c}-0.080^{* * *} \\
(0.023)\end{array}$ \\
\hline Children & & $\begin{array}{l}0.043^{*} \\
(0.020)\end{array}$ & $\begin{array}{l}0.041^{*} \\
(0.020)\end{array}$ \\
\hline Any Phys./Cog. Difficulty & & $\begin{array}{c}-0.331^{* * *} \\
(0.019)\end{array}$ & $\begin{array}{c}-0.338^{* * *} \\
(0.019)\end{array}$ \\
\hline Year 2011 & & & $\begin{array}{l}0.030^{*} \\
(0.013)\end{array}$ \\
\hline State FE & & & $\checkmark$ \\
\hline Race & & $\checkmark$ & $\checkmark$ \\
\hline Employment Status & & $\checkmark$ & $\checkmark$ \\
\hline Marital Status & & $\checkmark$ & $\checkmark$ \\
\hline $\mathrm{N}$ & 102,552 & 101,639 & 101,639 \\
\hline
\end{tabular}

With the above regressions providing some evidence that living in a MGHH results in decreased political participation, I move on to the differences-in-differences analysis with the hope of making a stronger causal claim. Using the data I have described above for this analysis, I perform a simple differences-in-differences regression on all the data prior to matching. These results can be found in Table 4 . Column 1 shows that those who became MGHH residents by wave 2 compared to those who did not saw an expected decrease in their political engagement scores of 0.15 , however, this is not significant. Including year and state fixedeffects slightly changes this estimate to a decrease of 0.16 , which is significant at the 0.1 level. While the 
sign on becoming a MGHH resident is in the expected direction, the significance of these results leaves much to be desired. Matching should result in a comparison of more similar people, while also reducing model dependence introduced by the inclusion of covariates.

Table 4: Differences-in-differences for CPS Civic Engagement Supplement Respondents; 2008-2011

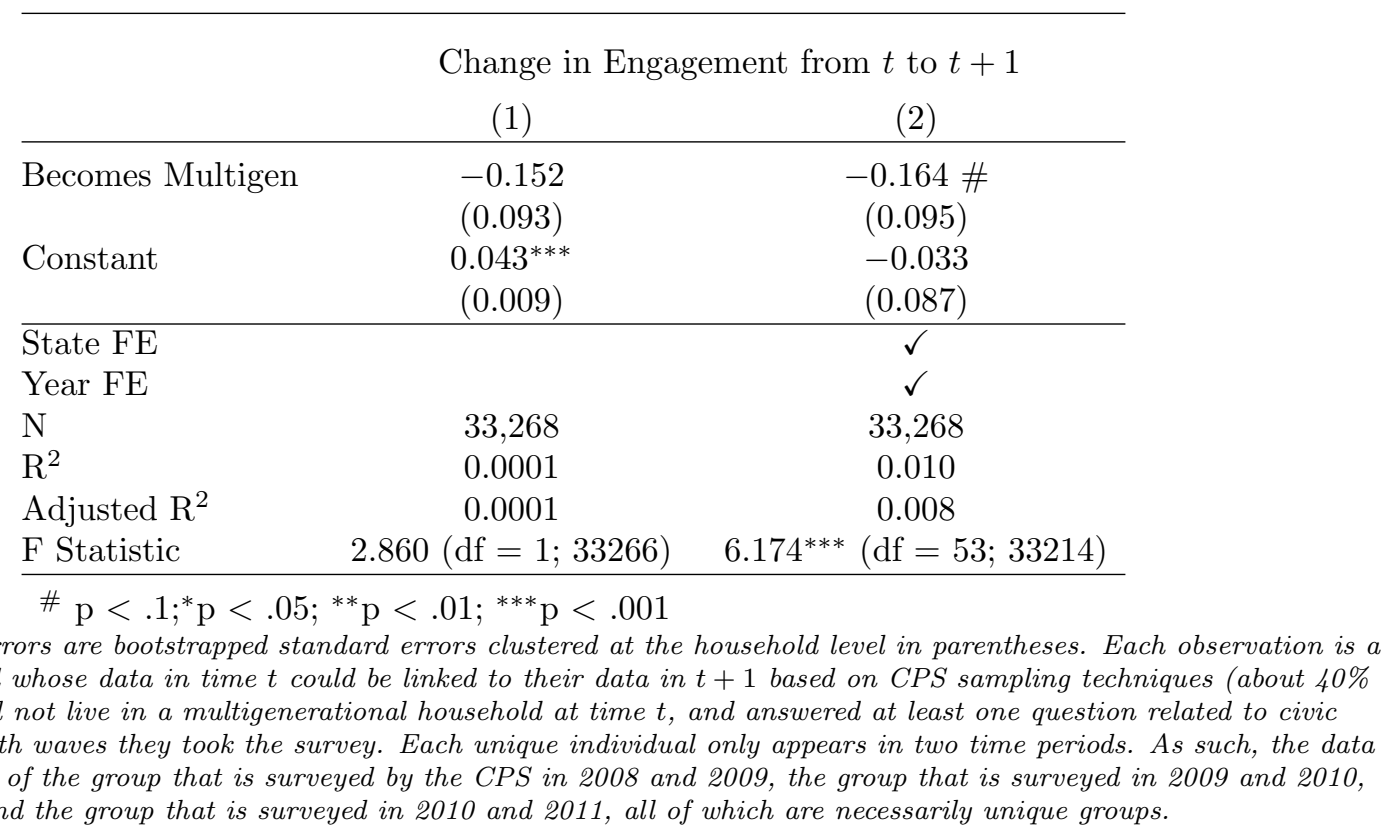

After carrying out the first matching process explained above, the data set is reduced to 133 observations. The results of the differences-in-differences regression using this data appear in Table 5 , columns 1, 2, and 3. Both with and without controlling for matched pretreatment covariates, columns 1 and 2 show that becoming a MGHH resident causes a significant decrease of about .7 in civic engagement score. As a quick reminder, this scale ranges from 0 to 9 in the full sample, and a 1 unit decrease would be equivalent to not engaging in a civic activity that one used to do. Column 3 includes year and state fixed-effects, and the estimated effect of becoming a MGHH resident increases slightly in magnitude, although is no longer significant. It is likely that the 133 observations do not result in a enough degrees of freedom to properly estimate a fixed-effects model, but I include this result for the sake of completeness.

Columns 4, 5, and 6 match on more demographic variables, and as a result, only have 55 observations. Without controlling for matched, pretreatment covariates, column 4 shows the estimated effect of a decrease of 1.19 in overall civic engagement score for those who become MGHH residents. Columns 4 and 5 show 
similar effects, however are not significant, likely in part to the small amount of observations. Table 6 repeats the exact same analysis, except the data that is used for matching is subset to include only those whose employment and marital status remain constant across the two waves, hopefully eliminating the concern that a drastic life change forces someone into a MGHH and also alters civic engagement. The statistically reliable estimates for the effect of becoming a MGHH resident in Table 6 range from -0.85 to -1.66 . Overall, this differences-in-differences analysis suggests that becoming a MGHH resident causes an individual to participate in one less civically engaged activity than when living in a traditional household. If it is the case that civic engagement is one of the factors that influence political participation (Putnam, 2000), this would offer an explanation as to why those living in MGHH participate at a lower rate.

\section{Concluding Remarks}

This paper has leveraged individual-level household relationships and records of traditional and non-traditional forms of political participation, along with the CPS rotation pattern and associated unique individual IDs to investigate multiple aspects of the political behavior of multigenerational households using various research

methods. Across multiple specifications, individuals in multigenerational households exhibit lower levels of political engagement than traditional, nuclear-family households, including lower voter turnout at the national and local levels and lower rates of civic community engagement, such as contacting public officials, discussing politics with friends and family, and participating in community associations, boards, or committees. These results suggest both that the increase in multigenerational households presents a potentially worrisome trend in political engagement of individuals in these households and that political campaigns may want to target MGHH specifically to increase participation. In future research I intend to investigate the sources of this difference in political behavior. 
Table 5: Differences-in-differences for Matched CPS Civic Engagement Supplement Respondents; 2008-2011

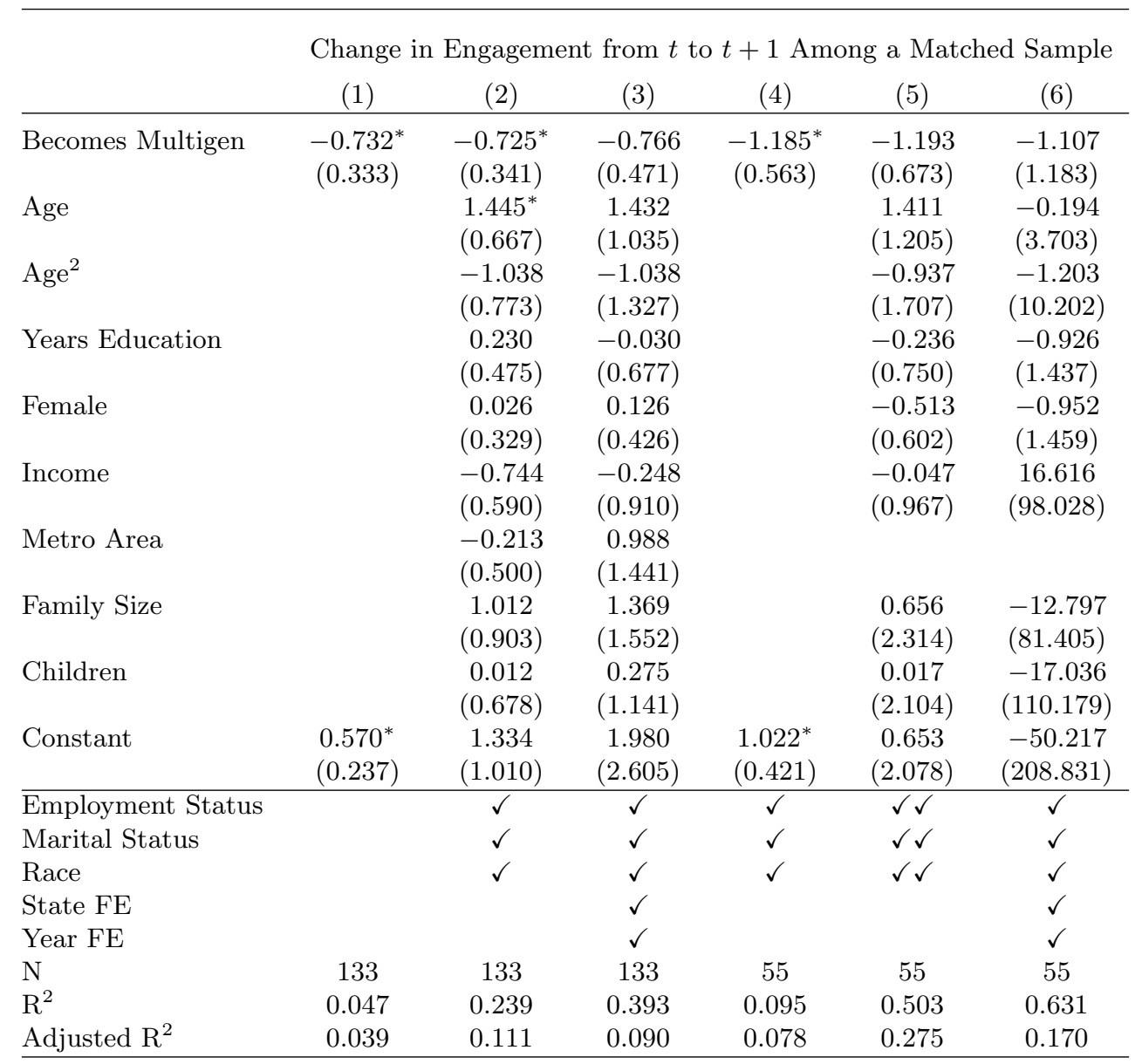

${ }^{*} \mathrm{p}<.05 ;{ }^{* *} \mathrm{p}<.01 ;{ }^{* * *} \mathrm{p}<.001$

Note: Standard errors are bootstrapped standard errors clustered at the household level. Matching is done with replacement, so more than one control unit can be matched to a treated unit. Weights are included in the regression to account for this. Columns 1, 2, and 3 match on state, year, age, family size, number of children, born in the United States, income, years of education, race, gender, and metro area. Columns 4, 5, and 6 match on all the previous variables and martial status, employment status, hours usually worked, and whether or not the individual has a physical or cognitive difficulty. The bins for age are 18-26, 27-36, 37-56, 57-66, 67-85. The bins for family size are 1, 2, 3-4, 5, 6-13. The bins for number of children are 0, 1, 2, 3, 4-6, 7-9. The bins for income range from $\$ 0$ to $\$ 150,000$ in increments of $\$ 10,000$. The bins for years of education are 0-8, 9-12, 13-16, and 17-20. The bins for hours usually worked are 0-5, 6-20, 21-45, 46-55, 56-80, 81-120, and 121-160. Continuous variables are standardized after matching by centering them at 0 and dividing by $2 \sigma$. As such, the coefficients can be interpreted as the effect of moving from the low end to the high end, roughly the same as how a binary variable would be interpreted. The standard errors in column 6 are so large because there aren't enough degrees of freedom for state and year fixed effects, so results should be interpreted with caution. 
Table 6: Differences-in-differences for Matched CPS Civic Engagement Supplement Respondents where Employment and Marital Status Remains Constant from $t$ to $t+1 ; 2008-2011$

\begin{tabular}{|c|c|c|c|c|c|c|}
\hline & \multicolumn{6}{|c|}{ Change in Engagement from $t$ to $t+1$ Among a Matched Sample } \\
\hline & $(1)$ & $(2)$ & $(3)$ & $(4)$ & $(5)$ & $(6)$ \\
\hline \multirow[t]{2}{*}{ Becomes Multigen } & $-0.916^{*}$ & $-0.854^{*}$ & -0.958 & $-1.412^{*}$ & $-1.663^{* *}$ & -2.187 \\
\hline & $(0.378)$ & $(0.338)$ & $(0.519)$ & $(0.617)$ & $(0.628)$ & $(177.908)$ \\
\hline \multirow[t]{2}{*}{ Age } & & 1.058 & 1.857 & & 1.974 & 1.948 \\
\hline & & $(0.708)$ & $(1.124)$ & & $(1.162)$ & $(9.394)$ \\
\hline \multirow[t]{2}{*}{$\mathrm{Age}^{2}$} & & -1.145 & -1.061 & & -1.204 & 4.345 \\
\hline & & $(0.753)$ & $(1.174)$ & & $(1.859)$ & $(30.633)$ \\
\hline \multirow[t]{2}{*}{ Years Education } & & 0.415 & -0.043 & & 0.126 & -0.662 \\
\hline & & $(0.424)$ & $(0.710)$ & & $(0.694)$ & $(6.937)$ \\
\hline \multirow[t]{2}{*}{ Female } & & -0.234 & -0.425 & & -0.562 & -1.661 \\
\hline & & $(0.387)$ & $(0.611)$ & & $(0.734)$ & $(6.646)$ \\
\hline \multirow[t]{2}{*}{ Income } & & $-1.307^{*}$ & -0.385 & & -0.126 & -48.601 \\
\hline & & $(0.604)$ & $(1.012)$ & & $(0.881)$ & $(660.655)$ \\
\hline \multirow[t]{2}{*}{ Metro Area } & & 0.104 & 0.819 & & & \\
\hline & & $(0.568)$ & $(1.610)$ & & & \\
\hline \multirow[t]{2}{*}{ Family Size } & & 0.985 & 1.527 & & 1.249 & 37.578 \\
\hline & & $(1.288)$ & $(1.988)$ & & $(2.589)$ & $(424.657)$ \\
\hline \multirow[t]{2}{*}{ Children } & & 0.005 & -0.382 & & -0.255 & 61.074 \\
\hline & & $(0.998)$ & $(1.744)$ & & $(2.400)$ & $(840.255)$ \\
\hline \multirow[t]{2}{*}{ Constant } & $0.660^{*}$ & 2.257 & 2.754 & $1.075^{*}$ & 2.908 & 23.544 \\
\hline & $(0.294)$ & $(1.401)$ & $(2.790)$ & $(0.489)$ & $(2.047)$ & $(699.741)$ \\
\hline Employment Status & & $\checkmark$ & $\checkmark$ & $\checkmark$ & $\checkmark \checkmark$ & $\checkmark$ \\
\hline Marital Status & & $\checkmark$ & $\checkmark$ & $\checkmark$ & $\checkmark \checkmark$ & $\checkmark$ \\
\hline Race & & $\checkmark$ & $\checkmark$ & $\checkmark$ & $\checkmark \checkmark$ & $\checkmark$ \\
\hline State FE & & & $\checkmark$ & & & $\checkmark$ \\
\hline Year FE & & & $\checkmark$ & & & \\
\hline $\mathrm{N}$ & 107 & 107 & 107 & 49 & 49 & 49 \\
\hline $\mathrm{R}^{2}$ & 0.064 & 0.417 & 0.540 & 0.121 & 0.599 & 0.753 \\
\hline Adjusted $\mathrm{R}^{2}$ & 0.055 & 0.289 & 0.272 & 0.102 & 0.398 & 0.408 \\
\hline
\end{tabular}

Note: Standard errors are bootstrapped standard errors clustered at the household level. Matching and analysis are performed exactly as in Table 5, except this data only includes individuals whose employment status and marital status do not change from time $t$ to time $t+1$. The standard errors in column 6 are so large because there aren't enough degrees of freedom for state fixed effects, so results should be interpreted with caution. Year fixed effects not included in column 6 because only 1 year is in the matched data. 


\section{References}

Aldrich, John H. 1993. "Rational Choice and Turnout." American Journal of Political Science 37(1):246.

Brady, Henry E., Sidney Verba and Kay Lehman Schlozman. 1995. "Beyond SES: A Resource Model of Political Participation." American Political Science Review 89(02):271-294.

Campbell, Angus, ed. 1964. The American Voter: An Abridgement. New York/N.Y. u.a: Wiley. OCLC: 325666 .

Carrns, Ann. 2017. "Multigenerational Households: The Benefits, and Perils." The New York Times .

Cohn, D’Vera and Jeffrey S. Passel. 2016. "Record 64 Million Americans Live in Multigenerational Households.".

Dahan, Charles and James E. Monogan. 2016. "The Consequences of Religious Strictness for Political Participation." The Social Science Journal 53(2):190-198.

Flood, Sarah, Miriam King, Renae Rodgers, Steven Ruggles and J. Robert Warren. 2018. "Integrated Public Use Microdata Series." Current Population Survey Version 6.0 [dataset]. Minneapolis, MN: IPUMS, 2018. https://doi.org/10.18128/D030.V6.0.

Fowler, James H. and Christopher T. Dawes. 2008. "Two Genes Predict Voter Turnout." The Journal of Politics 70(3):579-594.

Gelman, Andrew. 2008. "Scaling Regression Inputs by Dividing by Two Standard Deviations." Statistics in Medicine 27(15):2865-2873.

Gelman, Andrew and Jennifer Hill. 2007. Data Analysis Using Regression and Multilevel/Hierarchical Models. Analytical Methods for Social Research Cambridge ; New York: Cambridge University Press. OCLC: ocm67375137.

Gerber, Alan S., Donald P. Green and Christopher W. Larimer. 2008. "Social Pressure and Voter Turnout: Evidence from a Large-Scale Field Experiment." American Political Science Review 102(1):33-48.

Green, Donald P. 2015. Get Out the Vote. Brookings Institution Press. OCLC: 922703215. 
Hersh, Eitan. 2015. Hacking the Electorate: How Campaigns Perceive Voters. New York, NY: Cambridge University Press.

Hobbs, William R., Nicholas A. Christakis and James H. Fowler. 2014. "Widowhood Effects in Voter Participation." American Journal of Political Science 58(1):1-16.

Holbrook, Thomas M. and Scott D. McClurg. 2005. "The Mobilization of Core Supporters: Campaigns, Turnout, and Electoral Composition in United States Presidential Elections." American Journal of Political Science 49(4):689-703.

Hopkins, Daniel J. and Thad Williamson. 2012. "Inactive by Design? Neighborhood Design and Political Participation." Political Behavior 34(1):79-101.

Iacus, Stefano M., Gary King and Giuseppe Porro. 2012. "Causal Inference without Balance Checking: Coarsened Exact Matching." Political Analysis 20(01):1-24.

Lancaster, Tony. 2000. "The Incidental Parameter Problem since 1948." Journal of Econometrics 95(2):391413.

Lofquist, Daphne A. 2012. "Multigenerational Households: 2009-2011." p. 7.

Muennig, Peter, Boshen Jiao and Elizabeth Singer. 2018. "Living with Parents or Grandparents Increases Social Capital and Survival: 2014 General Social Survey-National Death Index." SSM - Population Health 4:71-75.

Multigenerational Households. 2019. https://www.gu.org/explore-our-topics/multigenerational-households/.

Niederhaus, Sharon Graham and John L. Graham. 2013. All in the Family: A Practical Guide to Successful Multigenerational Living. Lanham: Taylor Trade Publishing.

Putnam, Robert D. 2000. Bowling Alone: The Collapse and Revival of American Community. New York: Simon \& Schuster.

Rosenstone, Steven J. and John Mark Hansen. 1993. Mobilization, Participation, and Democracy in America. 
New Topics in Politics New York: Macmillan Pub. Co : Maxwell Macmillan Canada : Maxwell Macmillan International.

Stoker, Laura and M. Kent Jennings. 1995. "Life-Cycle Transitions and Political Participation: The Case of Marriage." American Political Science Review 89(02):421-433.

Tam Cho, Wendy K. 1999. "Naturalization, Socialization, Participation: Immigrants and (Non-)Voting." The Journal of Politics 61(4):1140-1155. 


\section{Appendix}

Figure 5: Distribution of Overall Civic Engagement Measure

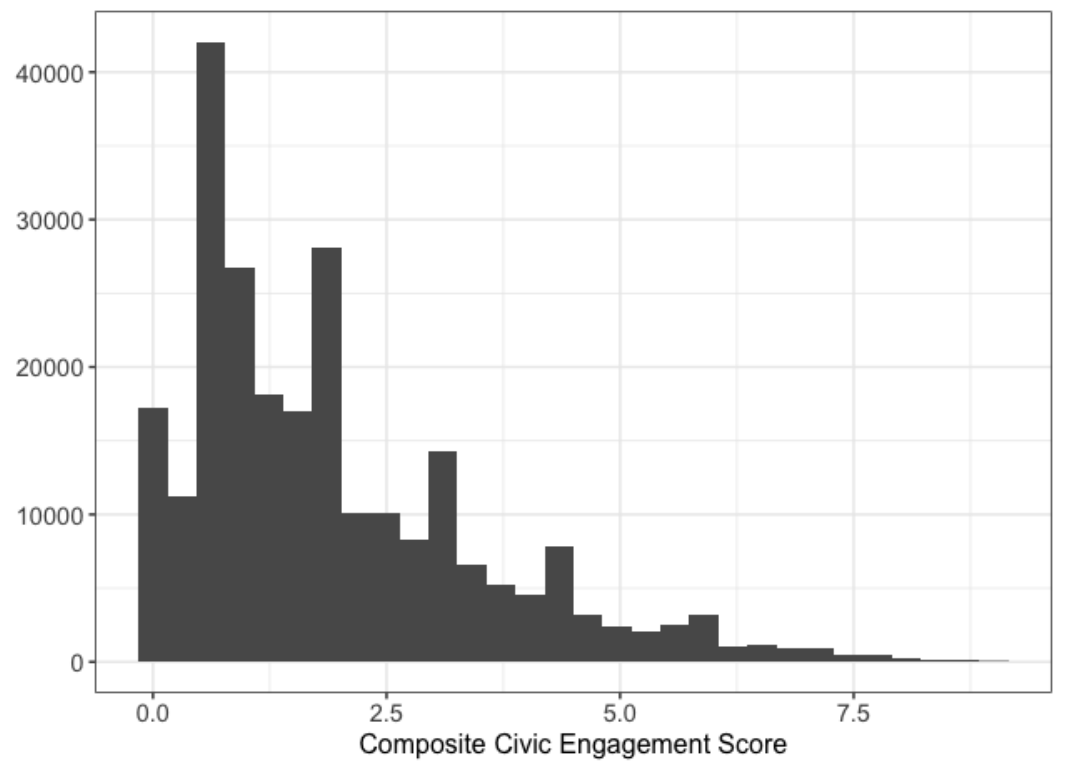

Note: Those who did not provide an answer to any of the civic engagement questions are removed from the data.

Figure 6: Trend of Pretreatment Civic Engagement

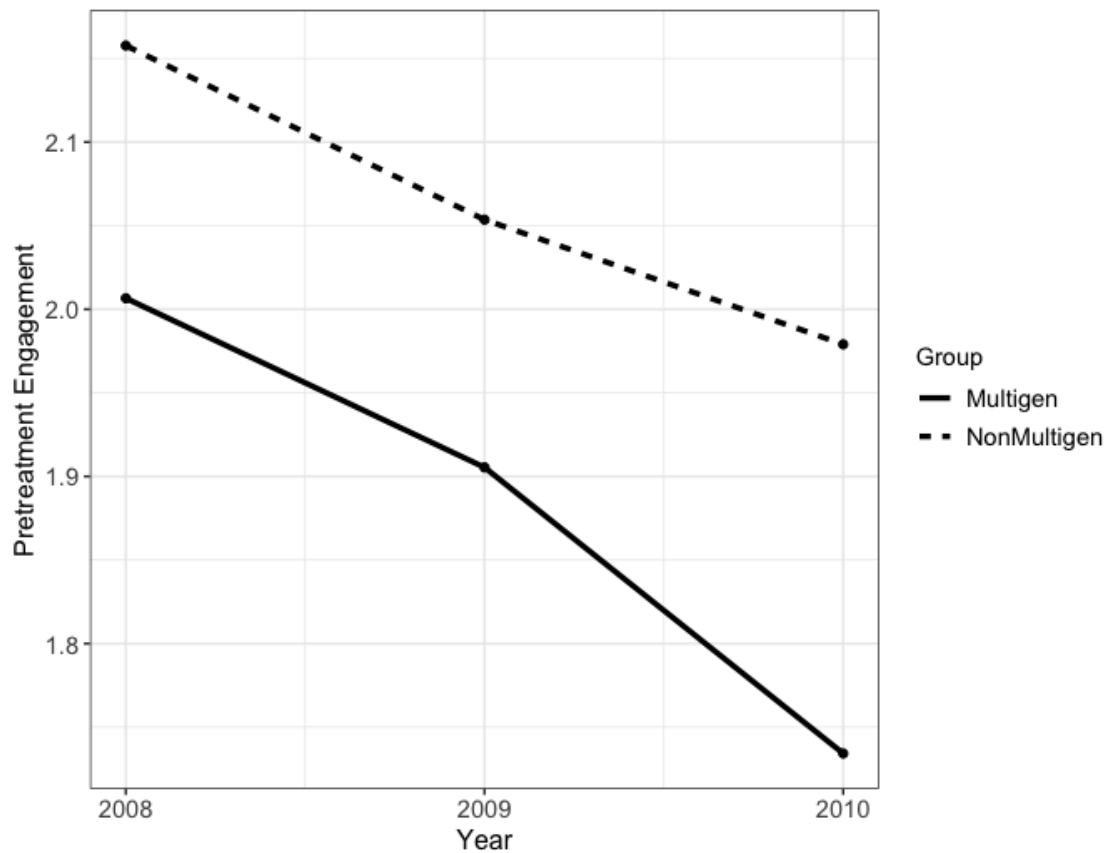

Note: The average of pretreatment engagement is measured for each treatment group within each year. An individual's pretreatment measure is only available in 1 year, as such this plot displays cross-sectional trends, not panel trends. 
Table 7: Effect of Living in a Multigenerational Household on Turnout in Presidential or Midterm Elections for CPS Voter Supplement Respondents; 2000-2016; Extended

\begin{tabular}{|c|c|c|c|c|}
\hline & \multicolumn{4}{|c|}{ Voted in Presidential or Midterm Election } \\
\hline & (1) & $(2)$ & $(3)$ & (4) \\
\hline Multigenerational & $\begin{array}{c}-0.132^{* * *} \\
(0.003)\end{array}$ & $\begin{array}{c}-0.040^{* * *} \\
(0.003)\end{array}$ & $\begin{array}{c}-0.028^{* * *} \\
(0.004)\end{array}$ & $\begin{array}{c}-0.026^{* * *} \\
(0.004)\end{array}$ \\
\hline Age & & $\begin{array}{c}0.264^{* * *} \\
(0.002)\end{array}$ & $\begin{array}{c}0.229^{* * *} \\
(0.002)\end{array}$ & $\begin{array}{c}0.232^{* * *} \\
(0.002)\end{array}$ \\
\hline $\mathrm{Age}^{2}$ & & $\begin{array}{c}-0.051^{* * *} \\
(0.003)\end{array}$ & $\begin{array}{c}-0.016^{* * *} \\
(0.003)\end{array}$ & $\begin{array}{c}-0.018^{* * *} \\
(0.003)\end{array}$ \\
\hline Years Education & & $\begin{array}{c}0.206^{* * *} \\
(0.001)\end{array}$ & $\begin{array}{c}0.194^{* * *} \\
(0.002)\end{array}$ & $\begin{array}{c}0.194^{* * *} \\
(0.002)\end{array}$ \\
\hline Female & & $\begin{array}{c}0.036^{* * *} \\
(0.001)\end{array}$ & $\begin{array}{c}0.035^{* * *} \\
(0.001)\end{array}$ & $\begin{array}{c}0.035^{* * *} \\
(0.001)\end{array}$ \\
\hline Asian & & $\begin{array}{c}-0.075^{* * *} \\
(0.007)\end{array}$ & $\begin{array}{c}-0.096^{* * *} \\
(0.009)\end{array}$ & $\begin{array}{c}-0.076^{* * *} \\
(0.009)\end{array}$ \\
\hline Black & & $\begin{array}{c}0.153^{* * *} \\
(0.006)\end{array}$ & $\begin{array}{c}0.142^{* * *} \\
(0.008)\end{array}$ & $\begin{array}{c}0.163^{* * *} \\
(0.008)\end{array}$ \\
\hline Hispanic & & $\begin{array}{c}0.034^{* * *} \\
(0.006)\end{array}$ & $\begin{array}{c}0.005 \\
(0.008)\end{array}$ & $\begin{array}{c}0.026^{* * *} \\
(0.008)\end{array}$ \\
\hline Other & & $\begin{array}{l}0.022^{* *} \\
(0.007)\end{array}$ & $\begin{array}{l}0.022^{*} \\
(0.009)\end{array}$ & $\begin{array}{c}0.035^{* * *} \\
(0.009)\end{array}$ \\
\hline White & & $\begin{array}{c}0.054^{* * *} \\
(0.006)\end{array}$ & $\begin{array}{c}0.038^{* * *} \\
(0.008)\end{array}$ & $\begin{array}{c}0.051^{* * *} \\
(0.008)\end{array}$ \\
\hline Income & & $\begin{array}{c}0.096^{* * *} \\
(0.001)\end{array}$ & $\begin{array}{c}0.083^{* * *} \\
(0.002)\end{array}$ & $\begin{array}{c}0.080^{* * *} \\
(0.002)\end{array}$ \\
\hline Born in U.S. & & $\begin{array}{c}0.072^{* * *} \\
(0.002)\end{array}$ & $\begin{array}{c}0.070^{* * *} \\
(0.003)\end{array}$ & $\begin{array}{c}0.072^{* * *} \\
(0.003)\end{array}$ \\
\hline NILF & & $\begin{array}{c}-0.040^{* * *} \\
(0.001)\end{array}$ & $\begin{array}{c}-0.034^{* * *} \\
(0.002)\end{array}$ & $\begin{array}{c}-0.030^{* * *} \\
(0.002)\end{array}$ \\
\hline Unemployed & & $\begin{array}{c}-0.052^{* * *} \\
(0.003)\end{array}$ & $\begin{array}{c}-0.043^{* * *} \\
(0.004)\end{array}$ & $\begin{array}{c}-0.039^{* * *} \\
(0.004)\end{array}$ \\
\hline Metro Area & & $\begin{array}{c}-0.003^{*} \\
(0.001)\end{array}$ & $\begin{array}{c}0.001 \\
(0.002)\end{array}$ & $\begin{array}{l}0.004^{*} \\
(0.002)\end{array}$ \\
\hline Family Size & & $\begin{array}{l}0.006^{* *} \\
(0.002)\end{array}$ & $\begin{array}{c}-0.022^{* * *} \\
(0.003)\end{array}$ & $\begin{array}{c}-0.018^{* * *} \\
(0.003)\end{array}$ \\
\hline Children & & $\begin{array}{c}-0.015^{* * *} \\
(0.002)\end{array}$ & $\begin{array}{l}-0.003 \\
(0.002)\end{array}$ & $\begin{array}{c}-0.005^{*} \\
(0.002)\end{array}$ \\
\hline Any Phys./Cog. Difficulty & & & $\begin{array}{c}-0.080^{* * *} \\
(0.002)\end{array}$ & $\begin{array}{c}-0.081^{* * *} \\
(0.002)\end{array}$ \\
\hline Resident $<1 \mathrm{yr}$ & & & $\begin{array}{c}-0.130^{* * *} \\
(0.002)\end{array}$ & $\begin{array}{c}-0.131^{* * *} \\
(0.002)\end{array}$ \\
\hline Constant & $\begin{array}{c}0.655^{* * *} \\
(0.001)\end{array}$ & $\begin{array}{c}0.527^{* * *} \\
(0.008)\end{array}$ & $\begin{array}{c}0.502^{* * *} \\
(0.008)\end{array}$ & $\begin{array}{c}0.578^{* * *} \\
(0.010)\end{array}$ \\
\hline State FE & & $\checkmark$ & & $\checkmark$ \\
\hline Year FE & & $\checkmark$ & & $\checkmark$ \\
\hline Marital Status & & $\checkmark$ & $\checkmark$ & $\checkmark$ \\
\hline $\mathrm{N}$ & 698,620 & 604,812 & 363,028 & 363,028 \\
\hline $\mathrm{R}^{2}$ & 0.003 & 0.200 & 0.167 & 0.212 \\
\hline Adjusted $\mathrm{R}^{2}$ & 0.003 & 0.199 & 0.167 & 0.212 \\
\hline
\end{tabular}

${ }^{*} \mathrm{p}<.05 ;{ }^{* *} \mathrm{p}<.01 ;{ }^{* * *} \mathrm{p}<.001$

Note: Standard errors in parentheses. Coefficients are from a linear probability model. Continuous variables are standardized by centering them at 0 and dividing by $2 \sigma$. As such, these coefficients can be interpreted as the effect of moving from the low end to the high end, roughly the same as how a binary variable would be interpreted. Observations are dropped in columns 3 and 4 because the physical or cognitive difficult variable was introduced to the CPS in 2008. 
Table 8: Effect of Living in a Multigenerational Household on Turnout in Presidential or Midterm Elections for CPS Voter Supplement Respondents, Logistic; 2000-2016; Extended

\begin{tabular}{|c|c|c|c|c|c|}
\hline & \multirow{3}{*}{$\begin{array}{c}\text { logistic } \\
(1)\end{array}$} & \multirow{3}{*}{\multicolumn{2}{|c|}{ 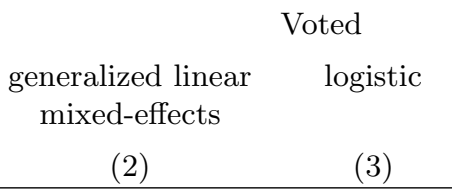 }} & \multirow{2}{*}{\multicolumn{2}{|c|}{$\begin{array}{l}\text { generalized linear } \\
\text { mixed-effects }\end{array}$}} \\
\hline & & & & & \\
\hline & & & & $(4)$ & $(5)$ \\
\hline Multigenerational & $\begin{array}{c}-0.548^{* * *} \\
(0.012)\end{array}$ & $\begin{array}{c}-0.192^{* * *} \\
(0.016)\end{array}$ & $\begin{array}{c}-0.132^{* * *} \\
(0.020)\end{array}$ & $\begin{array}{c}-0.131^{* * *} \\
(0.020)\end{array}$ & $\begin{array}{c}-0.171^{* * *} \\
(0.042)\end{array}$ \\
\hline Age & & $\begin{array}{c}1.413^{* * *} \\
(0.009)\end{array}$ & $\begin{array}{c}1.203^{* * *} \\
(0.012)\end{array}$ & $\begin{array}{c}1.296^{* * *} \\
(0.012)\end{array}$ & $\begin{array}{c}1.296^{* * *} \\
(0.012)\end{array}$ \\
\hline $\mathrm{Age}^{2}$ & & $\begin{array}{c}-0.111^{* * *} \\
(0.014)\end{array}$ & $\begin{array}{l}0.058^{* *} \\
(0.018)\end{array}$ & $\begin{array}{l}0.047^{*} \\
(0.019)\end{array}$ & $\begin{array}{l}0.046^{*} \\
(0.019)\end{array}$ \\
\hline Years Education & & $\begin{array}{c}1.218^{* * *} \\
(0.008)\end{array}$ & $\begin{array}{c}1.129^{* * *} \\
(0.010)\end{array}$ & $\begin{array}{c}1.194^{* * *} \\
(0.010)\end{array}$ & $\begin{array}{c}1.195^{* * *} \\
(0.010)\end{array}$ \\
\hline Female & & $\begin{array}{c}0.173^{* * *} \\
(0.006)\end{array}$ & $\begin{array}{c}0.166^{* * *} \\
(0.008)\end{array}$ & $\begin{array}{c}0.175^{* * *} \\
(0.008)\end{array}$ & $\begin{array}{c}0.175^{* * *} \\
(0.008)\end{array}$ \\
\hline Asian & & $\begin{array}{c}-0.477^{* * *} \\
(0.035)\end{array}$ & $\begin{array}{c}-0.572^{* * *} \\
(0.044)\end{array}$ & $\begin{array}{c}-0.485^{* * *} \\
(0.047)\end{array}$ & $\begin{array}{c}-0.488^{* * *} \\
(0.047)\end{array}$ \\
\hline Black & & $\begin{array}{c}0.772^{* * *} \\
(0.031)\end{array}$ & $\begin{array}{c}0.700^{* * *} \\
(0.040)\end{array}$ & $\begin{array}{c}0.854^{* * *} \\
(0.043)\end{array}$ & $\begin{array}{c}0.850^{* * *} \\
(0.042)\end{array}$ \\
\hline Hispanic & & $\begin{array}{c}0.192^{* * *} \\
(0.031)\end{array}$ & $\begin{array}{c}0.033 \\
(0.040)\end{array}$ & $\begin{array}{c}0.160^{* * *} \\
(0.043)\end{array}$ & $\begin{array}{c}0.156^{* * *} \\
(0.042)\end{array}$ \\
\hline Other & & $\begin{array}{c}0.070 \\
(0.038)\end{array}$ & $\begin{array}{c}0.070 \\
(0.047)\end{array}$ & $\begin{array}{c}0.143^{* *} \\
(0.050)\end{array}$ & $\begin{array}{l}0.142^{* *} \\
(0.050)\end{array}$ \\
\hline White & & $\begin{array}{c}0.234^{* * *} \\
(0.029)\end{array}$ & $\begin{array}{c}0.141^{* * *} \\
(0.038)\end{array}$ & $\begin{array}{c}0.221^{* * *} \\
(0.040)\end{array}$ & $\begin{array}{c}0.219^{* * *} \\
(0.040)\end{array}$ \\
\hline Income & & $\begin{array}{c}0.570^{* * *} \\
(0.008)\end{array}$ & $\begin{array}{c}0.465^{* * *} \\
(0.009)\end{array}$ & $\begin{array}{c}0.474^{* * *} \\
(0.010)\end{array}$ & $\begin{array}{c}0.475^{* * *} \\
(0.010)\end{array}$ \\
\hline Born in U.S. & & $\begin{array}{c}0.363^{* * *} \\
(0.013)\end{array}$ & $\begin{array}{c}0.347^{* * *} \\
(0.016)\end{array}$ & $\begin{array}{c}0.378^{* * *} \\
(0.017)\end{array}$ & $\begin{array}{c}0.378^{* * *} \\
(0.017)\end{array}$ \\
\hline NILF & & $\begin{array}{c}-0.200^{* * *} \\
(0.008)\end{array}$ & $\begin{array}{c}-0.153^{* * *} \\
(0.010)\end{array}$ & $\begin{array}{c}-0.138^{* * *} \\
(0.011)\end{array}$ & $\begin{array}{c}-0.138^{* * *} \\
(0.011)\end{array}$ \\
\hline Unemployed & & $\begin{array}{c}-0.223^{* * *} \\
(0.016)\end{array}$ & $\begin{array}{c}-0.172^{* * *} \\
(0.019)\end{array}$ & $\begin{array}{c}-0.166^{* * *} \\
(0.020)\end{array}$ & $\begin{array}{c}-0.166^{* * *} \\
(0.020)\end{array}$ \\
\hline Metro Area & & $\begin{array}{c}-0.028^{* * *} \\
(0.008)\end{array}$ & $\begin{array}{l}-0.005 \\
(0.009)\end{array}$ & $\begin{array}{c}0.013 \\
(0.011)\end{array}$ & $\begin{array}{c}0.013 \\
(0.011)\end{array}$ \\
\hline Family Size & & $\begin{array}{c}0.046^{* * *} \\
(0.011)\end{array}$ & $\begin{array}{c}-0.084^{* * *} \\
(0.014)\end{array}$ & $\begin{array}{c}-0.065^{* * *} \\
(0.014)\end{array}$ & $\begin{array}{c}-0.064^{* * *} \\
(0.014)\end{array}$ \\
\hline Children & & $\begin{array}{c}-0.088^{* * *} \\
(0.010)\end{array}$ & $\begin{array}{c}-0.037^{* *} \\
(0.013)\end{array}$ & $\begin{array}{c}-0.052^{* * *} \\
(0.013)\end{array}$ & $\begin{array}{c}-0.053^{* * *} \\
(0.013)\end{array}$ \\
\hline Any Phys./Cog. Difficulty & & & $\begin{array}{c}-0.414^{* * *} \\
(0.012)\end{array}$ & $\begin{array}{c}-0.447^{* * *} \\
(0.013)\end{array}$ & $\begin{array}{c}-0.447^{* * *} \\
(0.013)\end{array}$ \\
\hline Resident $<1 \mathrm{yr}$ & & & $\begin{array}{c}-0.606^{* * *} \\
(0.012)\end{array}$ & $\begin{array}{c}-0.650^{* * *} \\
(0.012)\end{array}$ & $\begin{array}{c}-0.650^{* * *} \\
(0.012)\end{array}$ \\
\hline Constant & $\begin{array}{c}0.640^{* * *} \\
(0.003)\end{array}$ & $\begin{array}{l}-0.142 \\
(0.160)\end{array}$ & $\begin{array}{c}0.011 \\
(0.043)\end{array}$ & $\begin{array}{l}-0.064 \\
(0.241)\end{array}$ & $\begin{array}{l}-0.061 \\
(0.229)\end{array}$ \\
\hline$\overline{\text { State RE }}$ & & $\checkmark$ & & $\checkmark$ & $\checkmark$ \\
\hline Year RE & & $\checkmark$ & & $\checkmark$ & $\checkmark$ \\
\hline State Varying Slopes & & & & & $\checkmark$ \\
\hline Year Varying Slopes & & & & & $\checkmark$ \\
\hline Marital Status & & $\checkmark$ & $\checkmark$ & $\checkmark$ & $\checkmark$ \\
\hline $\mathrm{N}$ & 698,620 & 604,812 & 363,028 & 363,028 & 363,028 \\
\hline
\end{tabular}


Table 9: Effect of Living in a Multigenerational Household on Turnout in Local Elections for CPS Civic Engagement Supplement Respondents, Ordered Logistic; 2011 \& 2013; Expanded

\begin{tabular}{|c|c|c|c|}
\hline & $\begin{array}{l}\text { Vote in Lo } \\
\text { (1) }\end{array}$ & $\begin{array}{l}\text { Elections: } \\
(2)\end{array}$ & 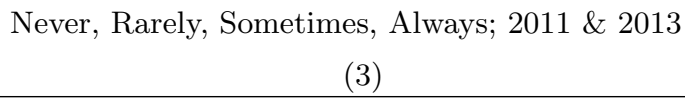 \\
\hline Multigenerational & $\begin{array}{c}-0.522^{* * *} \\
(0.028)\end{array}$ & $\begin{array}{c}-0.092^{* *} \\
(0.033)\end{array}$ & $\begin{array}{c}-0.099^{* *} \\
(0.033)\end{array}$ \\
\hline Age & & $\begin{array}{c}1.442^{* * *} \\
(0.018)\end{array}$ & $\begin{array}{c}1.457^{* * *} \\
(0.018)\end{array}$ \\
\hline $\mathrm{Age}^{2}$ & & $\begin{array}{l}-0.254^{* * *} \\
(0.029)\end{array}$ & $\begin{array}{l}-0.250^{* * *} \\
(0.029)\end{array}$ \\
\hline Years Education & & $\begin{array}{c}0.877^{* * *} \\
(0.014)\end{array}$ & $\begin{array}{c}0.881^{* * *} \\
(0.014)\end{array}$ \\
\hline Female & & $\begin{array}{c}0.074^{* * *} \\
(0.012)\end{array}$ & $\begin{array}{c}0.077^{* * *} \\
(0.012)\end{array}$ \\
\hline Asian & & $\begin{array}{c}-0.501^{* * *} \\
(0.073)\end{array}$ & $\begin{array}{c}-0.522^{* * *} \\
(0.075)\end{array}$ \\
\hline Black & & $\begin{array}{c}0.474^{* * *} \\
(0.065)\end{array}$ & $\begin{array}{c}0.544^{* * *} \\
(0.067)\end{array}$ \\
\hline Hispanic & & $\begin{array}{l}-0.110 \\
(0.067)\end{array}$ & $\begin{array}{c}0.010 \\
(0.068)\end{array}$ \\
\hline Other & & $\begin{array}{l}0.0001 \\
(0.078)\end{array}$ & $\begin{array}{l}-0.017 \\
(0.079)\end{array}$ \\
\hline White & & $\begin{array}{c}0.035 \\
(0.063)\end{array}$ & $\begin{array}{c}0.101 \\
(0.064)\end{array}$ \\
\hline Income & & $\begin{array}{l}0.282^{* * *} \\
(0.015)\end{array}$ & $\begin{array}{l}0.279^{* * *} \\
(0.015)\end{array}$ \\
\hline Born in U.S. & & $\begin{array}{c}0.531^{* * *} \\
(0.025)\end{array}$ & $\begin{array}{c}0.534^{* * *} \\
(0.026)\end{array}$ \\
\hline NILF & & $\begin{array}{c}-0.093^{* * *} \\
(0.016)\end{array}$ & $\begin{array}{c}-0.097^{* * *} \\
(0.016)\end{array}$ \\
\hline Unemployed & & $\begin{array}{c}-0.106^{* * *} \\
(0.030)\end{array}$ & $\begin{array}{c}-0.119^{* * *} \\
(0.030)\end{array}$ \\
\hline Metro Area & & $\begin{array}{c}-0.189^{* * *} \\
(0.015)\end{array}$ & $\begin{array}{c}-0.167^{* * *} \\
(0.016)\end{array}$ \\
\hline Family Size & & $\begin{array}{c}-0.083^{* * *} \\
(0.023)\end{array}$ & $\begin{array}{c}-0.080^{* * *} \\
(0.023)\end{array}$ \\
\hline Children & & $\begin{array}{l}0.043^{*} \\
(0.020)\end{array}$ & $\begin{array}{l}0.041^{*} \\
(0.020)\end{array}$ \\
\hline Any Phys./Cog. Difficulty & & $\begin{array}{c}-0.331^{* * *} \\
(0.019)\end{array}$ & $\begin{array}{c}-0.338^{* * *} \\
(0.019)\end{array}$ \\
\hline Year 2011 & & & $\begin{array}{l}0.030^{*} \\
(0.013)\end{array}$ \\
\hline $\begin{array}{l}\text { State FE } \\
\text { Marital Status }\end{array}$ & & & \\
\hline $\mathrm{N}$ & 102,552 & 101,639 & 101,639 \\
\hline
\end{tabular}

